\title{
Educational Status of Sumi Women in Zunheboto District, Nagaland: Changing Dimensions
}

\author{
Y. Inaholi Kiba \\ Research Scholar, St. Joseph University, Nagaland, India \\ Received: 11 Oct 2021; Received in revised form: 07 Nov 2021; Accepted: 18 Nov 2021 \\ (C2021 The Author(s). Published by TheShillonga. This is an open access article under the CC BY license \\ (https://creativecommons.org/licenses/by/4.0/)
}

\begin{abstract}
This paper focuses on the educational status of Sumi women. It discusses the factors influencing education of Sumi women and also identifies the hindrances in the path of their education. Some of the key findings show that there is parental/family and societal support for women education. Women also feel that education elevates their status in society and leads to their empowerment both socially and economically. However, women are not involved in the decision making process concerning matters related to their villages and town thereby reflecting the patriarchal nature of the society which has never recognised women as primary decision makers. In addition, lack of economic resources contributes towards neglect of women education especially in rural areas.
\end{abstract}

Keywords-Education, Sumi, Women, Patriarchy.

\section{INTRODUCTION}

Education is regarded as the cornerstone of progress and development. It is essential to the advancement of human civilisation. Education encourages good and constructive life improvements. People become civilised, skilled, aware, and responsible as a result of their education. It is also the most important factor in personal development. A country cannot develop appropriately unless it has the needed educated manpower. Nearly half of the world's population is made up of women. They are critical to a country's progress. It is an essential step for all countries, to enhance their female education situation. Education is a fundamental right, and along with educational facilities, discrimination based on sexes or gender must be eliminated. Unfortunately, gender discrimination still persists in many sections of our society. It is critical to convey to the public that female education is a fundamental right that should be made available to all women.

Women's education is aimed at empowering women to become economically self-sufficient. Women, as mothers, serve as educators in their homes, passing on what they learn to their children and future generations (Osuala, 1987). Women need to be educated in order to have a healthy and happy life. A well-educated woman can be a better person, a good mother, and a responsible citizen. Women's education will undoubtedly improve their living standards both within and outside the house. Educating women promotes self-respect and aids in the advancement of women's standing. A well-educated woman is aware of her legal rights.

Numerous studies by World Bank and other organisations has shown that illiterate women have high levels of fertility and mortality, poor nutritional status, low earning potential, and little autonomy within the household. A woman's lack of education also has a negative impact on the health and well being of her children. Apart from this, children of illiterate woman are also malnourished. Illiteracy also reduces the overall earning potential of the family and has a negative impact on economic growth as it lowers the average level of human capital. It has been found that girls who have no secondary education are six times more likely to end up as child brides in countries that have the greatest rates of child marriage (Kovacs, 2020). In addition women are also more susceptible to diseases than men. HIV/AIDS rate among women particularly in SubSaharan Africa has increased over the years and are twice as likely to become infected with HIV/AIDS as males (Kovacs, 2020). 
Literate women, on the other hand, are better able to make informed decisions for their families and are more likely to invest nearly all of their wealth in their families (Kovacs, 2020). They are also less likely to have children at an early age, lowering their chance of problems during childbirth. Investing in female education creates options for young women. Women's education increases their earnings, and their educational returns are frequently higher than men's. A World Bank report stated that a country with more educated girls and women is not just healthier, but wealthier (Grant, 1993). Educating women thus becomes important for improving the quality of life for women all around the world while also benefiting society as a whole.

Sumi Naga tribe is one of the major tribe in Nagaland. The traditions and customs practiced by Sumi's distinguish itself among other Naga tribes. Sumi have patriarchal family system where the patrilineal ideology determines the succession pattern. Zunheboto district is the home of the Sumi Naga that lies in the heart of Nagaland. The population of Zunheboto district according to 2011 census stands at $1,40,757$ out of which male constitutes 71,217 and female 69,540 . The literate population of Zunheboto district is $1,02,881$ out of which 53,504 is male and 49,377 is female. The literacy rate in the district according to 2011 census is 85.26 per cent out of which 87.85 per cent is male and 82.62 per cent is female (Nagaland Statistical Handbook, 2020)

\section{Objectives}

1. To examine the educational status of Sumi women

2. To analyse the factors influencing education of Sumi women

3. To identify the hindrances in the path of Sumi women's education

\section{METHODOLOGY}

This section highlights a review of the research design:

\section{Sources of Data Collection:}

Both quantitative and qualitative methods were used in collecting data. Primary data were obtained from both questionnaire administration and personal interviews. Data derived through questionnaire administration was supplemented by data collected by interviewing key informants. Secondary data were generated on the basis of extensive literature survey and sources such as books, journals, reports and newspapers.

\section{Sample Design}

Stratified Random Sampling method was applied for the selection of appropriate sample for the present study. Educated Sumi women who have passed class 10 and are continuing their studies are part of the sample. In addition working women, housewives and career women who are literate having certain educational qualification are also included in the sample. Altogether a total of 400 respondents (200 urban and 200 rural) were randomly selected.

\section{Data Analysis:}

Quantitative data from survey was analysed using simple method of calculation. Qualitative data from in-depth interviews was transcribed, translated and analysed.

\section{RESULTS AND DISCUSSION}

Much research has been done to explore the root causes of women illiteracy. Some of the barriers include poverty, parents and societal negative attitudes, insufficient school infrastructure, early marriage and pregnancy etc. This section highlights some of the key findings of the study. Emphasis has been made on women's status and attitude, parental and societal perceptions, economic factors and women's empowerment.

Table 1: Parental/Family's support

\begin{tabular}{|c|c|c|c|}
\hline \multicolumn{2}{|c|}{ Parental / Family's support } & \multicolumn{2}{c|}{ Percentage } \\
\hline \multicolumn{2}{|c|}{ Yes } & No \\
\hline 1 & Objection towards schooling & 2 & 98 \\
\hline 2 & Gender bias towards education & 3 & 97 \\
\hline 3 & Were parents treatment liberal & 94 & 6 \\
\hline 4 & $\begin{array}{c}\text { Encouragement for higher } \\
\text { education }\end{array}$ & 95 & 5 \\
\hline
\end{tabular}

Source: Field work, 2020

To realise the educational ambition of a woman, it is pertinent that family support is rendered. 98 per cent of the respondents did not face any parental objection towards their schooling and also did not face any discrimination based on gender. 94 per cent of them also believe that their parents treated them liberally and got support and encouragement to pursue higher education (Table 1).

Table 2: Societal Acceptance

\begin{tabular}{|c|c|c|c|}
\hline \multicolumn{2}{|r|}{ Societal Acceptance } & \multicolumn{2}{|c|}{ Percentage } \\
\hline & & Yes & $\mathrm{No}$ \\
\hline 1 & $\begin{array}{c}\text { Do society accept you as } \\
\text { a capable being }\end{array}$ & 91 & 9 \\
\hline 2 & $\begin{array}{l}\text { Are your views and } \\
\text { opinion respected }\end{array}$ & 93 & 7 \\
\hline 3 & $\begin{array}{l}\text { Do you take } \\
\text { responsibilities in society }\end{array}$ & 87 & 13 \\
\hline
\end{tabular}




\begin{tabular}{|c|c|c|c|}
\hline 4 & $\begin{array}{c}\text { Do you get privilege for } \\
\text { being educated }\end{array}$ & 94 & 6 \\
\hline
\end{tabular}

Source: Field work, 2020

Societal support is another major factor which influences women's education. Data from table 2 shows that 91 per cent of the respondents feel that they are accepted as capable people in society. Majority of them also accepts that their views and opinions are respected. 87 per cent of them also take up responsibilities concerning the welfare of their society.

\section{Table 3: Economic factors}

\begin{tabular}{|c|c|c|c|}
\hline \multicolumn{2}{|c|}{ Economic factors } & \multicolumn{2}{c|}{ Percentage } \\
\hline \multicolumn{2}{|c|}{} & Yes & No \\
\hline 2 & $\begin{array}{l}\text { Neglected education due to } \\
\text { lack of economic resources }\end{array}$ & 61 & 39 \\
\hline $\begin{array}{l}\text { Higher economic status have } \\
\text { more educational privileges }\end{array}$ & 82 & 18 \\
\hline
\end{tabular}

Source: Field work, 2020

As is the case in many societies lack of economic resources has been found to be one of the major factors hindering women's education. Families with low income cannot afford enough money to educate their children, so they choose their son for higher education. Girls thus are generally confined to the domestic activities like aiding their mothers in doing the household chores, caring for their younger siblings and occasionally working to earn income. In the present study also 61 per cent of the respondents are of the view that limited economic resources acts as a stumbling block towards realisation of women's education. Moreover 82 per cent of the respondents also agree that those women from higher economic strata enjoy better educational privileges. These results clearly indicate the importance of economic factor as a variable in influencing women's education (Table 3)

Table 4: Women empowerment

\begin{tabular}{|c|c|c|c|}
\hline \multicolumn{2}{|c|}{ Women Empowerment } & \multicolumn{2}{c|}{ Percentage } \\
\hline 1 & $\begin{array}{c}\text { Empowerment of women is } \\
\text { priority issue }\end{array}$ & 98 & 2 \\
\hline 2 & $\begin{array}{c}\text { Are you involved in family } \\
\text { decision-making }\end{array}$ & 90 & 10 \\
\hline 5 & $\begin{array}{c}\text { Are you involved in decision } \\
\text { making in matters pertaining } \\
\text { to villages/town }\end{array}$ & 18 & 82 \\
\hline 4 & \begin{tabular}{c} 
Women need to be elevated \\
\hline
\end{tabular} & 98 & 2 \\
\hline
\end{tabular}

\begin{tabular}{|c|c|c|c|}
\hline 5 & $\begin{array}{c}\text { to decision-making position } \\
\text { (whether traditional } \\
\text { customary issues need to } \\
\text { change }\end{array}$ & 96 & 4 \\
\hline
\end{tabular}

Source: Field work, 2020

Women empowerment is the pivotal part in any society. It is a woman who plays a dominant role in the basic life of a child. Women are important assets of our society. Education as means of empowerment of women can bring about a positive attitudinal change. It is therefore, crucial for the socioeconomic and political progress of any nation. Table 4 shows that 98 per cent of the respondents feel that empowerment of women are priority issue which needs to be addressed. 90 per cent of the respondents opined that they are also integral part in family decision making process. However it is at the decision making process in their villages and town that they are not involved. This clearly reflects the patriarchal nature of Sumi society which has never recognised women as primary decision makers. It is on account of such exclusion that many of the respondents feel that traditional customary laws should be refined so as to enable women to take part in decision making process (Table 4).

Table 5: Women attitude towards education

\begin{tabular}{|c|c|c|c|}
\hline \multicolumn{2}{|c|}{ Women attitude towards education } & \multicolumn{2}{c|}{ Percentage } \\
\hline 1 & $\begin{array}{c}\text { Does education change } \\
\text { cultural values and traditions }\end{array}$ & 82 & 18 \\
\hline 2 & $\begin{array}{c}\text { Girls should get married at an } \\
\text { early age }\end{array}$ & 1 & 99 \\
\hline 3 & $\begin{array}{c}\text { Compulsory girls education } \\
\text { need of the hour }\end{array}$ & 99 & 1 \\
\hline 4 & $\begin{array}{c}\text { Attitude of men towards } \\
\text { women's education is } \\
\text { changing }\end{array}$ & 97 & 3 \\
\hline
\end{tabular}

Source: Field work, 2020

The trend towards women's education has changed over the decades. As a result of efforts put by governments and civil society educational levels of women has gone up. This has in turn resulted in change of attitude towards education. Table 5 shows that 82 per cent of the respondents concur that education has helped change cultural values and tradition. In addition 99 per cent of them are not in favor of early marriage. Majority of them also believes that compulsory girl education is the need of the hour. Finally majority of them also believed that men's attitude towards women's education is changing. 


\section{CONCLUSION}

This paper was set out to examine the educational status of Sumi women in Zunheboto district, Nagaland. It also attempted to bring out the factors influencing women's education and also identify hindrances. From the results discussed above it can be said that the attitudes regarding women's education has changed for the better. Majority of the respondents faced no discrimination from parents and society when it came to their education. They also received encouragement to pursue higher education and are regarded as capable people in society. Their views and opinions are respected and that education helps in elevating their social status. They are also of the view that early marriage is not desirable and that girl education should be made compulsory so as to realise their full potential. This study has also identified that lack of economic resources hampers women's education and also that women are still not a part of decision making process especially in matters relating to their villages and town. Thus efforts should be made to make education more accessible and affordable so that girl's from lower economic strata are also able to get access to education. Lastly society as a whole should discard those aspects of tradition and customs which inhibit the participation of women in the decision making process.

\section{REFERENCES}

[1] Grant, P.J. (1993). Girls and Women A Unicef Development Priority. New York, U.S.A.

[2] Jimomi, Inavi. (2018). Sumi Naga -The origin and migration of the Nagas. Heritage Publishing House (HPH Books) Dimapur, Nagaland

[3] Kovacs, E. (2020). 5 Reasons to Invest in Girl's Education. Global Campaign for Education United States Chapter. Retrieved from http://campaignforeducationusa.org/blog/detail/5-reasons-toinvest-in-girls-education

[4] Sharmila, N., \& Dhas, C. A. (2010). Development of Women Education in India. Retrieved from: http://mpra.ub.unimuenchen.de/20680/MPRA

[5] Osuala, J.D.C. (1987). Basic Education Modules for Nigerian Women. Nigerian Audit Education and Community Development Education

[6] Statistical Handbook of Nagaland. (2020). Department of Economics and Statistics. Government of Nagaland. Kohima 